\title{
Dispeptik yakınmalarla acil servise müracat eden hastalarda etiyolojik değerlendirme
}

\author{
Etiological evaluation of patients who present to the emergency department with dyspeptic \\ complaints
}

(D) Hacı Mehmet ÇALIŞKAN', (D Burak ÇELIK², (DS Süleyman ERSOY'

Kırşehir Ahi Evran Üniversitesi, Tıp Fakültesi, 'Acil Tıp Anabilim Dalı, Kırşehir

Kırşehir Ahi Evran Üniversitesi, Eğitim ve Araştırma Hastanesi, ${ }^{2}$ Acil Servisi, Kırşehir

Giriş ve Amaç: Dispepsi üst batında hissedilen şişkinlik, ağrı, yanma, erken doyma, bulantı ve geğirti yakınmalarından oluşan bir semptomlar bileşkesidir. Acil servisler dispepsi yakınması olan hastaların sık başvurdukları sağlık hizmetlerinin sunulduğu merkezlerin başında gelmektedir. Bu durum, acil servislerde hem iş yükünü arttırmakta hem de yüksek sigorta maliyetlerine sebep olmaktadır. Bu çalışmada amaç, dispeptik yakınmalarla acil servise müracaat eden hastaların etiyolojik değerlendirilmesidir. Gereç ve Yöntem: Çalışmamı prospektif gözlemsel bir anket çalışması olup, 2019 yılı Mart-Haziran döneminde acil servise dispeptik yakınmalar ile başvuran hastalar üzerinde yapılmıştır. Hastalara çalışma hakkında gerekli açıklamalar yapıldıktan sonra, çalışmaya katılmaya gönüllü hastalardan yazılı onam alınarak anketler yüz yüze görüşme yöntemiyle uygulanmıştır. Çalışmaya 18 yaş üzerinde 386 gönüllü dahil edilmiştir. Bulgular: Hastaların yaş ortalaması $41.08 \pm 18.33$ yıl olup, \%65.8'i (254) kadın, \%34.19'u (132) erkekti. Hastaların \%52.6'sının ( $n=203)$ daha önce de dispeptik yakınmalarla acil servise başvurdukları, \%47.4'ünün ( $n=183$ ) ise ilk kez başvurduğu görüldü. Acil servise dispeptik yakınmalarla başvuran hastalarda kadın hastaların (\%61.8'i) erkeklere (\%30.3'ü) oranla daha fazla stres faktörüne sahip oldukları görüldü ve başvuran hastaların cinsiyete göre yeni başlayan bir stres faktörüne sahip olup olmamaları arasında istatistiksel olarak anlamlı bir fark tespit edildi $(p=0.000)$. Acil servise dispeptik yakınmalarla başvuran erkek hastaların kadınlara oranla daha fazla acı, ekşi ve tuzlu gıda tüketimi yaptıkları tespit edildi. Özellikle sigara içen erkeklerin dispeptik yakınmalarla daha fazla acil servise başvurduğu tespit edildi. 65 yaş üzerindeki hastaların ilaç alımı esnasında dispeptik yakınmalar nedeniyle acil servise diğer yaş gruplarına göre daha fazla başvurusu olduğu saptanmıştır. Sonuç: Çalışmamız sonucunda kadınlarda stres faktörü, erkeklerde sigara içme ve beslenme alışkanlıkları, geriatrik yaş grubunda ilaç yan etkileri ve gençlerde asitli içecek tüketiminin dispeptik yakınmaları arttırdığı tespit edilmiştir. Acil servise dispeptik yakınmalarla başvuran hastalara bahse konu yaşam tarzı değişikliğini içeren konularda bilgilendirme yapılmasının, her yaş grubu ve cinsiyetteki bireylerin dispeptik yakınma ve acil müdahale gerektirmeyen başvuruları azaltacağı kaçınılmaz bir sonuçtur.

Anahtar kelimeler: Dispepsi, epigastrik ağrı, epigastrik yanma, şişkinlik, acil servis

\section{GíRiş}

Dispepsi terimi, Yunanca'da "Dys" ve "pepsis" kelimesinden türemiş olup sindirim güçlüğü anlamına gelmektedir $(1,2)$. Dispepsi bir tanı değildir, bir semptomlar bileşkesi

iletişim: Hacı Mehmet ÇALIŞKAN

Kırşehir Ahi Evran Üniversitesi Tıp Fakültesi Acil Tıp A.B.D, Kırşehir

Tel: +90 3862134515

E-mail: hmehmet.40@hotmail.com
Background and Aims: Dyspepsia is a combination of symptoms that consists of bloating, pain, burning, early satiety, nausea, and burping. Patients with dyspeptic complaints frequently present to emergency departments. This situation increases the workload in emergency departments and causes high insurance costs. This study aims to investigate the causes of the increase in dyspeptic complaints of patients who present to emergency departments. Materials and Methods: This study was conducted as a prospective observational study from March to June 2019 with patients who presented to an emergency department with dyspeptic complaints. All data was acquired using faceto-face questionnaire after required explanations were provided to the patients. This study included 386 volunteers who were over the age of 18 years. Results: The mean age of the patients was $41.08 \pm 18.33$ years, $65.8 \%(n=254)$ were women and $34.19 \%(n=132)$ were men. It was observed that $52.6 \%(n=203)$ of the patients with dyspeptic complaints had presented to the emergency department previously, while $47.4 \%(n=183)$ presented for the first time. It was also observed that female patients (61.8\%) who presented to the emergency department with dyspeptic complaints had more stress factors than men (30.3\%). There was a statistically significant correlation between whether the presenting patients had a new stress factor or not ( $p=$ 0.000). Studies revealed that male patients who presented to the emergency department with dyspeptic complaints consumed more bitter, sour, and salty foods than women. Men with a smoking history were more often identified at the emergency department with dyspeptic complaints. Findings also revealed that patients over the age of 65 years present at the emergency department more often than other age groups after drug intake. Conclusion: In this study, we found that dyspeptic complaints increased with stress factors in females, smoking and dietary habits in males, side effects of medicine in the geriatric age group, and acidic beverage consumption in young people. Therefore, providing information on issues involving the required lifestyle changes in patients with dyspeptic complaints is necessary to reduce the number of presentations at emergency departments and complaints among patients across both genders and all age groups due to dyspepsia.

Key words: Dyspepsia, epigastric pain, epigastric burning, bloating, emergency department

olup üst batında hissedilen şişkinlik, ağrı, yanma, erken doyma, bulantı ve geğirtiyi içeren semptomlardan oluşur (1). Dispeptik yakınmalar genellikle gıda alımından son-

Çalışkan HM, Çelik, B, Ersoy S. Etiological evaluation of patients who present to the emergency department with dyspeptic complaints. The Turkish Journal of Academic Gastroenterology 2020;19:41-48. DOI: 10.17941/agd.800810

Geliş Tarihi: 01.05.2020 • Kabul Tarihi: 22.07.2020 
ra belirginleşir ve bazı gıdalar ile dikkat edilmesi gereken unsurlar (stres, sigara, ilaç kullanımı) bu şikayetlerin artmasına neden olmaktadır. Dispeptik yakınmalar, altta yatan organik bir nedenden (gastrit, peptik ülser, duedenal ülser, ya da gastrik duedenal kanserler gibi) kaynaklanabileceği gibi altta yatan organik, sistemik veya metabolik hiçbir nedenin bulunamadığı dispepsiler (fonksiyonel dispepsiler) olarak da gözlenebilmektedir (1-4).Fonksiyonel dispepsi 2008 yılında yayınlanan Roma III kriterlerine göre epigastrik ağrı, epigastrik yanma, postprandiyal dolgunluk, erken doyma gibi semptomlardan bir ya da daha fazlası ile birlikte endoskopik tetkikler dahil hiçbir organik nedenin bulunamadığı durumdur $(1,4,5)$. Bu semptomlar son altı ayın 3 ayında devam ediyor olmalıdır. Fonksiyonel dispepsi; epigastrik ağrı sendromu (EAS) ve postprandiyal distres sendromu (PDS) olarak iki alt guruba ayrılmışır $(4,5)$. Dispeptik yakınmaların etiyopatogenezinde genetik, fizyolojik, psikolojik ve birçok çevresel faktörün etkili olabileceği düşünülürken diyet, beslenme alışkanlıkları, yaşam tarzı ve sigara gibi etmenler de yakınmaları arttırabilmektedir $(4,6)$.

Dispeptik yakınmalar, ülkemizde ve dünyada oldukça yaygın olarak gözlenmektedir. Dispeptik yakınmaların prevalansı bölgeden bölgeye değişmekle birlikte Avrupa, Kuzey Amerika ve Okyanus ülkelerinde \%3-40 arasında değişen oranlara sahiptir (4). Acil servisler, her gün birçok dispeptik yakınma ile başvuran hastaların tedavi aldığı sağlık hizmeti sunulan merkezler olup, hastanın mevcut yakınma profiline göre tetkik ve belirtilere yönelik tedavi planları yapılmaktadır. Bu durum ise acil servislerde iş yükünün gereğinden fazla artmasına neden olmaktadır (7).

Bu çalışmada amaç, dispeptik yakınmalarla acil servise müracaat eden hastaların etiyolojik değerlendirilmesidir.

\section{GEREÇ ve YÖNTEM}

Bu çalışma, prospektif gözlemsel bir anket çalışmasıdır. Çalışma 2019 yılı Mart-Haziran döneminde acil servise epigastrik ağrı, epigastrik yanma, şişkinlik, erken doyma ve geğirti yakınmaları ile müracaat eden hastalar üzerinde yapıldı. Hastalara çalışma hakkında gerekli açıklamalar yapıldıktan sonra, çalışmaya katılmaya gönüllü hastalardan yazilı onam alınarak anketler yüz yüze görüşme yöntemiyle uygulanmıştır. Çalışmaya, 18 yaş üzerinde 386 gönüllü katılımcı dahil edilmiştir. Araştırmacılar tarafından güncel literatürler taranarak hazırlanmış olan anket soruları; katıımcıların demografik özelliklerini, daha önceden dispeptik yakınmaları arttırdığı tespit edilen stres, non-steroid antiinflamatuvar (NSAi) ilaç kullanımı, yaşam tarzı açııından davranış haline gelmiş beslenme alışkanIıkları (acı, ekşi veya tuzlu besin madddesi/gıda tüketimi), asitli içecek ve kahve tüketimi ve sıklığı, tütün maddeleri (sigara, nargile, vb.) kullanım durumu, günlük tüketilen su miktarı, daha önce aynı yakınmalarla acil servise başvuru sıklı̆ıı, endoskopi yapılıp yapılmadığı, tanı alıp almadığı ve mide asidi baskılayıcı ürünler [( $\mathrm{H} 2$ reseptör blokeri, proton pompa inhibitörü (PPi), vb] kullanma durumunu sorgulayan sorulardan oluşmaktaydı.

Katılımcılarda akut dispeptik yakınmalara neden olabilecek sistemik hastalık, safra taşı, pankreatit ve akut batına neden olabilecek hastalığı olanlar çalışmaya dahil edilmedi.

\section{İstatistik Yöntem}

Çalışmanın istatistiksel analizleri Statistical Package for Social Sciences version 21.0 software for Windows (IBM SPSS Statistics for Windows, Version 21.0. Armonk, NY: IBM Corp., USA) kullanılarak yapılmıştır. Kalitatif değişkenlere ait açıklayıı istatistikler $\mathrm{n}(\%)$ olarak verilmiştir. Kalitatif değişkenler arasındaki ilişkiyi ve gözlemlerin gruplara dağılımlarını test etmek için Ki-Kare testi kullanılmıştır. Tüm istatistik analizlerde $\mathrm{P}$ değeri 0.05 olarak alınmıştır.

\section{Etik Onay}

Çalışmanın etik kurulu onayı Ahi Evran Üniversitesi Tıp Fakültesi etik kurulundan 2019-02/29 karar No'su ile 29.01.2019 tarihinde alınmıştır. Çalışmada Helsinki Deklarasyonuna sadık kalındı. Çalışmaya dahil edilen katıııcılara gerekli açıklamalar yapıldıktan sonra yazıı onamları alındı.

\section{BULGULAR}

Çalışmaya acil servise dispeptik yakınmaları nedeniyle başvuran 386 hasta dahil edildi. Bu hastaların \%65.8'i (254) kadın, \%34.19'u (132) erkekti. Hastaların yaş ortalaması $41.08 \pm 18.33$ yıl olup; dağılım 18-85 yıldır (Tablo 1).

Tablo 1. Acil servise dispeptik yakınmalarla müracaat eden hastaların yaş gruplarına göre dağııımı.

\begin{tabular}{|lc|}
\hline Yaş Grupları (yıl) & Hasta Sayısı, $\mathbf{n}(\%)$ \\
\hline $18-25$ & 84 \\
\hline $26-35$ & 101 \\
\hline $36-45$ & 73 \\
\hline $46-55$ & 42 \\
\hline $56-65$ & 30 \\
\hline $66+$ & 56 \\
\hline Toplam & 386 \\
\hline
\end{tabular}


Acil servise dispeptik yakınmalar ile başvuran hastaların \%51'i ( $n=197$ ) son günlerde yeni başlayan bir stres faktörünün var olduğunu ifade etmiştir. Kadınların \%61.8'i ( $n=157$ ) yeni başlayan bir stres faktörünün var olduğunu bildirirken, erkeklerin ise \%30.3'ü $(n=40)$ yeni başlayan bir stres faktörünün var olduğunu ifade etmiştir. Acil servise dispeptik yakınmalar ile başvuran hastaların cinsiyete göre yeni başlayan bir stres faktörüne sahip olup olmamaları arasında istatistiksel olarak anlamlı bir fark tespit edilmiştir ( $\left.\chi^{2}=34.507 ; \mathrm{P}=0.000\right)$. Dispeptik yakınmalar ile başvuran kadın hastaların erkeklere oranla daha fazla stres faktörüne sahip oldukları saptanmıştır (Tablo 2).

Acil servise dispeptik yakınmalar ile başvuran hastalara dispepsi oluşturabilecek herhangi bir ilaç ya da özellikle antiinflamatuvar ilaç alıp almadıkları sorulduğunda \%62.7'sinin ( $n=242$ ) ilaç almadığı, \%37.3'ünün ( $n=144)$ ise aldığı tespit edilmiştir. Cinsiyetler ile ilaç alımı arasındaki ilişki incelendiğinde erkeklerin \%31.1'i ilaç kullanırken, kadınların \%40.6'sı ilaç kullanmakta idi. Cinsiyet ile ilaç kullanımı arasında istatistiksel olarak anlamlı bir fark tespit edilememiştir $\left(\chi^{2}=3.445 ; \mathrm{P}=0.067\right)$ (Tablo 2 ). Ancak ilaç kullanımı nedeni ile başvuran hastalar yaş aralıklarına göre değerlendirildiğinde, 65 yaş üzerinde dispeptik yakınmalar ile başvuran hastaların pik yaptığı gözlenmektedir (Grafik 1). Özellikle ileri yaşta dispeptik yakınmaların gözlenmesinin; artralji yakınmaları nedeni ile antiinflamatuvar ilaç kullanımı ve koroner arter hastalığı ile serebrovasküler hastalık profilaksisi için asetil salisilik asit kullanımından kaynaklandığı düşünülmektedir.

Dispeptik yakınmalar açısından önemli bir etken olan beslenme alışkanlıkları değerlendirildiğinde; acil servise başvuran hastalara son 6-8 saat içerisinde acı, ekşi veya aşırı tuzlu gıda tüketimi sorulduğunda hastaların \%61.9'unun ( $n=239)$ bu tür ürünleri tükettikleri tespit edilmiştir. Acl, ekşi veya aşırı tuzlu gıda tüketimi ile cinsiyet arasında istatistiksel olarak anlamlı bir fark olup olmadığını incelediğimizde erkeklerin (\%70.5'i) kadınlara (\%57.5'i) göre daha fazla bu tarz gıdaları tükettikleri tespit edilmiştir $\left(\chi^{2}=6.201 ; P=0.013\right)$. Acil servise dispeptik yakınmalar ile başvuran erkek hastaların kadınlara oranla daha fazla acı, ekşi ve tuzlu gıda tüketimi yaptıkları saptanmıştır (Tablo 2).

Dispeptik yakınmalar açısından diğer bir etken olan sigara içme durumu sorgulandığında, acil servise başvuran has-

Tablo 2. Cinsiyetlere göre stres faktörü, ilaç yan etki, diyet alışkanlıkları, sigara kullanımı, endoskopik tanı ve acil servise müracaat durumunun dağılımı.

\begin{tabular}{|c|c|c|c|c|}
\hline Değişkenler & & Kadın, $n(\%)$ & Erkek, n (\%) & $\mathbf{P}$ \\
\hline \multirow[t]{2}{*}{ Yeni başlayan stres ya da üzüntü } & Yok & $97(38.2)$ & $92(69.7)$ & \multirow{2}{*}{0.000} \\
\hline & Var & $157(61.8)$ & $40(30.3)$ & \\
\hline \multirow[t]{2}{*}{ Antibiyotik veya ağrı kesici kullanımı } & Yok & $151(59.4)$ & $91(68.9)$ & \multirow{2}{*}{0.067} \\
\hline & Var & $103(40.6)$ & $41(31.1)$ & \\
\hline \multirow[t]{2}{*}{ Acı, ekşi, tuzlu gıda tüketimi } & Yok & $108(42.5)$ & $39(29.5)$ & \multirow{2}{*}{0.013} \\
\hline & Var & $146(57.5)$ & $93(70.5)$ & \\
\hline \multirow[t]{3}{*}{ Sigara kullanımı (adet/gün) } & Yok & $163(64.2)$ & $39(29.5)$ & \multirow{3}{*}{0.000} \\
\hline & $<10$ & $60(23.6)$ & $33(25.0)$ & \\
\hline & 10 & $31(12.20)$ & $60(45.5)$ & \\
\hline \multirow[t]{2}{*}{ Asitli içecek tüketimi } & Yok & $126(49.6)$ & $62(47.0)$ & \multirow{2}{*}{0.623} \\
\hline & Var & $128(50.4)$ & $70(53.0)$ & \\
\hline \multirow[t]{4}{*}{ Su tüketimi (L) } & $0-1$ & $59(23.2)$ & $21(15.9)$ & \multirow{4}{*}{0.058} \\
\hline & $1-1.5$ & $157(61.8)$ & $78(59.1)$ & \\
\hline & $1.5-2.5$ & $33(13.0)$ & $27(20.5)$ & \\
\hline & $2.5^{+}$ & $5(2.0)$ & $6(4.5)$ & \\
\hline \multirow[t]{2}{*}{ Endoskopi ile tanı konulup konulmadığı } & Yok & $157(61.8)$ & $92(69.7)$ & \multirow{2}{*}{0.125} \\
\hline & Var & $97(38.2)$ & $40(30.3)$ & \\
\hline \multirow[t]{2}{*}{ Son bir yılda acile başvuru durumu } & Hayır & $113(44.5)$ & $70(53.0)$ & \multirow{2}{*}{0.111} \\
\hline & Evet & $141(55.5)$ & $62(47.0)$ & \\
\hline \multirow[t]{2}{*}{ Asit baskılayıcı ilaç kullanım öyküsü } & Hayır & $117(46.1)$ & $75(56.8)$ & \multirow{2}{*}{0.045} \\
\hline & Evet & $137(53.9)$ & $57(43.2)$ & \\
\hline
\end{tabular}




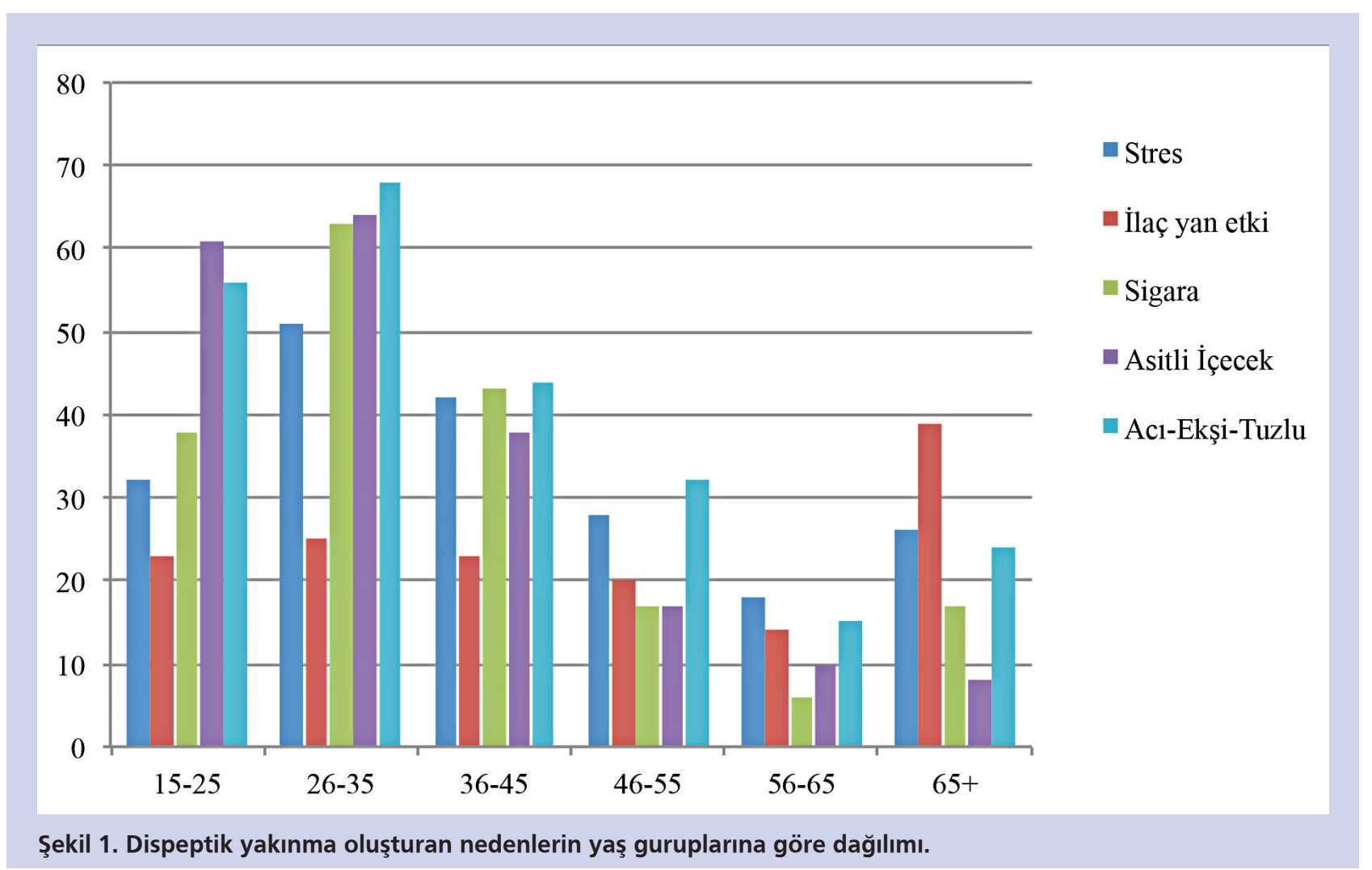

taların \%47.7'sinin (184) sigara içtiği tespit edilmiştir. Bu durum, toplumun sigara içme oranından daha yüksek bir orana denk gelmektedir ve sigara içenlerde dispeptik yakınmalar ile acil servise başvuru oranının daha fazla olduğunu düşündürmektedir. Sigara içenlerin \%24.1'i ( $n=93)$ günde $10^{\prime}$ dan az, \%23.6'sı (n=91) günde 10 veya daha fazla sigara içtiğini bildirmiştir. Cinsiyete göre sigara içme durumu incelendiğinde kadınların \%35.8'i, erkeklerin ise \%70.5'i sigara içmektedir. Bu oran, özellikle sigara içen erkeklerin akut dispeptik şikayetler ile daha fazla acil servise başvurduğunu göstermektedir. İlimizde diğer tütün ürünlerinden olan nargile tüketimi oldukça nadir olduğu için vakalarımızdan sadece 3 tanesi nargile içiyordu ki, o kişiler de nadiren nargile içtiklerini daha çok sigara tükettiklerini ifade ettiler. Biz bu kişileri de günde 10 adetten daha fazla sigara içenler gurubuna dahil ettik.

Dispeptik yakınmalar ile acil servise başvuran hastalara son 6-8 saat içerisinde asitli içecek ya da kahve içip içmedikleri sorulduğunda, hastaların \%51.3'ü (n=198) içtiklerini belirtmişlerdir. Cinsiyetlere göre asitli içecek ve kahve tüketimi incelendiğinde kadınların \%50.4'ü bu tür ürünleri tükettiğini belirtirken, erkeklerin \%53'ü asitli içecek ve kahve tükettiğini bildirmiştir. Asitli içecek veya kahve tüketimi ile cinsiyet arasında istatistiksel olarak anlamlı bir fark tespit edilememiştir $\left(\chi^{2}=0.242 ; P=0.623\right)$ (Tablo
2). Ancak yaş gruplarına göre asitli içecek dağılımı analiz edildiğinde 18-35 yaş arasında asitli içecek tüketiminin en fazla olduğu gözlenmiştir (Şekil 1).

Dispeptik yakınmalar ile acil servise başvuran hastaların günlük su tüketimleri incelendiğinde; hastaların \%20.7'sinin ( $n=80$ ) günde 1 L'den az su tükettiği, \%60.9'unun ( $n=235)$ 1-1.5 L arasında su tükettiği, \%15.5'inin ( $n=60)$ 1.5-2.5 L arasında su tükettiği, \%2.8'inin ise $(n=11) 2.5$ L'den fazla su tükettiği tespit edilmiştir. Bu durum, dispeptik yakınmalar ile acil servise başvuran hastaların yaklaşık \%81'inin günlük içmeleri gereken su miktarından daha az su tükettiklerini ve sıvı açı̆̆ını diğer içecekler ile karşıladıklarını düşündürmektedir. Çalışmamızdan edindiğimiz bilgilere göre 18-35 yaş arasındaki hastaların özellikle asitli sıvı tüketimi ile günlük sıvı ihtiyacını karşıladıkları, 35-45 yaşlar arasında ise sıvı ihtiyacının daha çok çay içimi ile karşılandığı tespit edilmiştir.

Dispeptik yakınmalar ile acil servise başvuran hastaların \%35.5'ine ( $n=137)$ daha önce endoskopi yapıldığı ve bunların bir kısmının gastrit ya da peptik ülser tanısı aldığı, bir çoğunun ise kesin tanısını bilmediği öğrenilmiştir. Hastaların \%64.5'inin ( $n=249)$ ise daha önce herhangi bir girişimsel işlem yaptırmadığı ve tanı almadığı öğrenilmiştir. 
Acil servise dispeptik yakınmalar ile başvuran 386 hastaya "son bir yıl içerisinde benzer bir şikâyetle acil servise başvurdunuz mu?" sorusu sorulduğunda; hastaların \%52.6'sının ( $n=203$ ) daha önce de benzer bir şikayetle acil servise başvurdukları \%47.4'ünün ( $n=183)$ ise acil servise ilk kez başvurduğu öğrenilmiştir. Son bir yıl içerisinde benzer şikâyetle acil servise başvurduğunu bildiren hastalardan \%29.56'sı (n=60) 1 kez, \%40.89'u (n=83) 2 kez, \%19.21'i (n=39) 3 kez, \%5.42'si (n=11) 4 kez ve \%4.93'ü ( $n=10)$ 5'den fazla geldiğini bildirmiştir (Tablo 2).

Dispeptik yakınma ile acil servise başvuran hastaların \%49.7'si ( $n=192$ ) daha önce mide asidi baskılayıc ilaç (PPi ya da $\mathrm{H} 2$ reseptör blokeri) kullanmadığını, \%50.3'ü ise ( $n=194)$ kullandığını ifade etmiştir. Asit baskılayıcı ilaç kullanımını cinsiyetlere göre incelediğimizde (Tablo 2) kadınların \%53.9'u bu tür ilaçları kullanırken erkeklerin ise \%43.2'si kullanmaktadır. Mide asidi baskılayıc ilaç kullanma durumu ile cinsiyet arasında istatistiksel olarak anlamlı bir ilişki vardır ( $\chi 2=4.019 ; \mathrm{P}=0.045)$. Kadın hastaların mide asidi baskılayıc ilaç kullanım oranı erkeklerden daha fazladır.

Son günlerde yeni başlayan ciddi bir üzüntü veya stres yaşama durumu ile acil servise başvuru sayılarının karşılaştırılması Tablo 3'te verilmiştir. Tabloda görüldüğü gibi stres faktörünün var olduğu bireylerin, olmayanlara göre daha fazla acil servis başvuruları olduğu görülmektedir. Son bir yılda acil servise 5'ten fazla başvuranların \%70'inde ya- şadığı üzücü bir olay veya stresin mevcut olduğu gözlenmiştir. Acile son bir yılda 4 kez başvuranların \%72.7'sinde stres veya üzücü bir durumla karşılaşma mevcuttur. Fakat her iki değişken arasındaki fark istatistiksel olarak anlamlı değildir ( $\chi^{2}=0.829 ; \mathrm{P}=0.934$ ) (Tablo 3).

Son bir yılda dispeptik yakınmalar ile acil servise başvuru sayısı ile sigara içme durumları arasındaki ilişki Tablo 4'de verilmiştir. Tablo 4'e göre son bir yılda acil servise başvuru sayısı ile sigara içme durumu arasında istatistiksel olarak anlamlı bir fark vardır $\left(\chi^{2}=15.985\right.$; $\left.P=0.043\right)$. Özellikle günde 10 adetten daha fazla sigara içen kişilerin (çoğunluğunu erkekler oluşturmakta) acil servise tıbbi yardım almak için çok daha fazla başvurdukları gözlenmiştir (Tablo 4).

\section{TARTIŞMA}

Yaptığımız bu çalışmadan elde ettiğimiz verilere göre acil servise dispeptik yakınmalar ile başvuran kadın hastalarda yeni başlayan stres faktörünün, erkeklerde sigara kullanımı ve beslenme alışkanlıklarının, yaşılarda özellikle antiinflamatuvar ilaçlar ve asetil salisilik asit kullanımının ve gençlerde ise içecek olarak su kullanımı yerine asitli içeceklerin tercih edilmesinin dispeptik yakınmaları arttırdığı tespit edilmiştir. Ayrıca stres faktörü yoğun olan kadınlar ile günde 10 adetten fazla sigara tüketen erkeklerin mükerrer kez dispeptik yakınmalar ile acil servise başvuru yaptığı tespit edilmiştir.

Tablo 3. Katılımcıların son bir yıl içerisinde dispeptik yakınmalar açısından ciddi bir üzüntü veya stres yaşama durumuna göre acile servise müracaat sayıları.

\begin{tabular}{|c|c|c|c|c|c|}
\hline Üzüntü veya & $1 \mathrm{Kez}$ & $2 \mathrm{Kez}$ & $3 \mathrm{Kez}$ & $4 \mathrm{Kez}$ & $5 \mathrm{Kez}$ ve Üzeri \\
\hline $\begin{array}{l}\text { Stres Yaşama } \\
\text { Durumu }\end{array}$ & $\begin{array}{c}\text { Müracaat } \\
\text { n (\%) }\end{array}$ & $\begin{array}{c}\text { Müracaat } \\
\text { n (\%) }\end{array}$ & $\begin{array}{c}\text { Müracaat } \\
\text { n (\%) }\end{array}$ & $\begin{array}{c}\text { Müracaat } \\
\text { n (\%) }\end{array}$ & $\begin{array}{c}\text { Müracaat } \\
\text { n (\%) }\end{array}$ \\
\hline Evet & $40(66.7)$ & $61(73.5)$ & $28(71.8)$ & $8(72.7)$ & $7(70)$ \\
\hline Hayır & $20(33.3)$ & $22(26.5)$ & $11(28.2)$ & $3(27.3)$ & $3(30)$ \\
\hline Toplam & 60 & 83 & 39 & 11 & 10 \\
\hline
\end{tabular}

Tablo 4. Katılımcıların son bir yıl içerisinde dispeptik yakınmalar açısından sigara tüketimine göre acil servise müracaat sayıları.

\begin{tabular}{|c|c|c|c|c|c|}
\hline $\begin{array}{l}\text { Sigara İçme } \\
\text { Durumu } \\
\text { (adet/gün) }\end{array}$ & $\begin{array}{c}1 \mathrm{Kez} \\
\text { Müracaat } \\
\mathrm{n}(\%)\end{array}$ & $\begin{array}{c}2 \mathrm{Kez} \\
\text { Müracaat } \\
\text { n (\%) }\end{array}$ & $\begin{array}{c}3 \mathrm{Kez} \\
\text { Müracaat } \\
\text { n (\%) }\end{array}$ & $\begin{array}{c}4 \mathrm{Kez} \\
\text { Müracaat } \\
\text { n (\%) }\end{array}$ & $\begin{array}{c}5 \text { Kez ve Üzeri } \\
\text { Müracaat } \\
\text { n (\%) }\end{array}$ \\
\hline Hayır & $35(58.3)$ & $36(43.4)$ & $13(33.3)$ & $5(45.5)$ & $4(40.0)$ \\
\hline Evet $<10$ & $18(30.0)$ & $22(26.5)$ & $9(23.1)$ & $3(27.3)$ & $1(10.0)$ \\
\hline$\geq 10$ & 7 (11.7) & $25(30.1)$ & $17(43.6)$ & $3(27.3)$ & $5(50.0)$ \\
\hline Toplam & 60 & 83 & 39 & 11 & 10 \\
\hline
\end{tabular}


Dispeptik yakınmalar ülkemizde ve dünyada oldukça yaygın olarak gözlenmektedir. Batı ülkelerinde dispepsinin görülme sıklı̆ı \%40'lara varan oranlarda bildirilmekte ise de ortalama olarak \%20-25 oranlarında olduğu kabul edilmektedir (1). Türkiye'de 1. basamakta aile hekimleri tarafından yapılan bir çalışmada Aile Sağlık Merkezi birimlerine başvuran hastaların \%44'ünde dispeptik yakınmaların gözlendiği belirtilmiştir (6). Tayland'da yapılan benzer bir çalışmada Tayland halkının \%66'sının dispeptik yakınmalara sahip olduğu belirtilmiştir (8). Fonksiyonel dispepsinin görülme sıklı̆ı da ülkeden ülkeye büyük farkllıklar göstermektedir. Örneğin Türkiye'de yapılan bir çaış̧mada \%12-15 oranında bildirilirken, Tayland'da yapılan bir çalışmada \%60-90 oranında olduğu belirtilmiştir $(5,8)$. Zagari ve arkadaşları ise 2010 ylında yaptıkları çalışmada, dispeptik semptomları olan vakaların \%72.6'sında normal endoskopik sonuçlar bulduklarını ifade etmişlerdir (9). Kore'de yapılan bir başka çalışmada ise fonksiyonel dispepsi prevalansının \%10 ile \%45 arasında değişik oranlarda gözlendiği belirtilmiştir (10). Acil servislere dispeptik yakınmalar ile başvuran hastaların başvuru sıklığı üzerine yapılmış bir çalışma bulunmamakta, ancak acil servislerde kullanılan PPI ve $\mathrm{H} 2$ reseptör blokeri sayısına bakıldığında hiç de azımsanmayacak oranda olduğu düşünülmektedir. Yapılan üç çalışmada dispepsi yakınmalarının \%68 ile kadınlarda daha fazla gözlendiği belirtilmiştir $(6,11,12)$. Bizim çalışmamızda da literatüre benzer olarak \%65.8 ile kadınlarda, \%34.19 oranında ise erkeklerde dispeptik yakınmalar gözlendiği tespit edildi.

Daha önce yapılan iki çalışmada yakın dönemde yaşanmış olan stresin abdominal rahatsızlığa neden olduğu ve bu yüzden stres nedenli akut dispeptik yakınmaların tedavisinde psikolojik yardım ve desteğin önemli olduğu belirtilmiştir $(7,13)$. İan'da yapılan benzer bir çalışmada psikolojik stres yaşayanlarda ve anksiyetesi olanlarda dispeptik yakınmaların daha fazla olduğu belirtilmiştir (14). Bizim çalışmamızda da acil servise dispeptik yakınmalar ile başvuran hastalarda yeni başlayan stres faktörünün önemli olduğu ve özellikle dispeptik yakınma ile başvuran kadınların erkeklere oranla daha fazla yeni başlayan strese sahip oldukları tespit edilmiştir.

Dispepsi oluşturan nedenler arasında önemli bir orana sahip olan diğer faktör de kullanılan ilaçlardır. Daha önce yapılan birçok çalışmada kortikosteroidler, non-steroid antiinflamatuvar analjezikler ve asetil salisilik asitin gastrik mukoza için oldukça toksik olup harabiyete neden olduğu belirtilmiştir $(1,15,16)$. Ali Özden tarafından yapılan çalışmada NSAi ilaç kullanan kişilerin \%15'inde ayda en az bir gün dispeptik yakınmanın olduğu belirtilmiştir (1). Bizim çalışmamızda dispeptik yakınması nedeniyle başvu- ran hastaların \%37.3'ünde non-steroid antiinflamatuvar analjezik ve asetil salisilik asit kullanımı mevcuttu. Özellikle 55-60 yaşına kadar hiç dispeptik yakınması olmamış bireylerin antiinflamatuvar ilaç tedavisi esnasında ciddi dispeptik yakınmalar ile acil servisimize başvurduklarını gözlemledik. Gastrik yan etkisi fazla olan ilaçlar tercih edilirken (özellikle de NSAI ilaçlar) hastanın daha önceden dispeptik yakınması olup olmadığının sorgulanması ve bu ilaçların kullanımı konusunda hasta eğitiminin daha iyi yapılması ve mümkünse gastrik yan etkisi en az olanların tercih edilmesinin dispeptik yakınmaları azaltacağı düşüncesindeyiz.

Dispeptik yakınmaların beslenme alışkanlıkları ile doğrudan ilişkili olduğu birçok makalede belirtilmiştir $(4,17,18)$. Fonksiyonel dispepsi düşünülen vakalarda da semptomları etkileyen faktörler arasında diyet ve yaşam tarzı önemli rol oynamaktadır $(4,17)$. Türk ve ark. tarafından yapılan çalışmada bizim çalışmamızda da olduğu gibi kahve, asitli içecekler, alkollü içecekler, baharatlı gıdalar ve sigara tüketiminin dispeptik semptomları arttırdığı belirtilmiştir (4). Köksal ve arkadaşları dispepsili hastalarda semptomları en fazla artıran nedenler olarak baharatlı beslenme ve sigara kullanımını göstermişlerdir (6). Bizim çalışmamızda ise baharatlı beslenme ve sigara kullanımının yanı sıra özellikle kadınlarda stres faktörünün ve 18-35 yaş arasında ise asitli içeceklerin önemli olduğu gözlemlendi.

Lee SY ve ark.'ı çalışmalarında baharatlı ve kabuklu besinlerin üst gastrointestinal sistem semptomlarını ve midede dolgunluk hissini arttırdığını belirtmişlerdir (18). Masoumi SJ ve ark. da fazla tuzlu yiyeceklerin fonksiyonel dispeptik semptomlarla ilişkili olduğunu bildirmişlerdir (11). Biz de çalışmamızda, bu sebeplerle dispeptik yakınma ile başvuran hastalara, özellikle son 6-8 saat içerisinde acı, ekşi ya da tuzlu gıda alıp almadıklarını sorduk ve özellikle erkeklerin (\%70.5 oranında) bu tür gıdalar yedikten sonra yakınmalarının daha fazla olduğunu gözlemledik.

Yapılan çalışmalarda, sigaranın, özellikle gastrik mukozada kan akımını ve bikarbonat üretimini azaltarak dispeptik yakınmalara neden olabileceği belirtilmiştir $(3,4)$. Bektaş $\mathrm{M}$ ve ark. tarafından yapılan çalışmada 1 paket ve üzerinde sigara içenlerde dispeptik yakınmaların 2.5 kat fazla gözlendiği belirtilmiştir (19). Türkiye'de yapılan bir başka çalışmada toplumun sigara içme oranının \%31.5 olduğu, erkeklerin \%47, kadınların ise \%11.6 oranında sigara içtiği belirtilmiştir (20). Bizim yaptığımız çalışmamızda, vakaların ortalama sigara içme oranı $\% 47.7$ bulunup, erkeklerin \%70.5'inin, kadınların ise \%35.8'inin sigara içtiği tespit edilmiş olup bu oranın toplumdaki sigara içme oranından daha yüksek olduğu gözlenmiştir. 
Asitli içecek tüketiminin birçok çalışmada dispeptik yakınmaları arttırdığından bahsedilmiş ve tedavide mutlak suretle asitli içeceklerden kaçınılması önerilmiştir $(21,22)$. $\mathrm{Biz}$ de bu sebeple acil servise dispeptik yakınmalar ile başvuran hastalara, son 6-8 saat içerisinde asitli içecek içip içmediklerini sorduk, yaşlara ve cinsiyetlere göre dağıımını araştırdık ve elde ettiğimiz sonuçlara göre 18-35 yaş arasındaki kişilerin diğer yaş guruplarına göre asitli içecekleri daha sık tükettiklerini tespit ettik. Ayrıca bu yaş gurubunda yemeklerin yanında içecek olarak su tüketimi yerine asitli içeceklerin daha fazla tercih edildiğini saptadık. Gençlere asitli sıvı içiminin zararlarının anlatılması, onun yerine su ya da probiyotik (ayran ve kefir) içeren içeceklerin önerilmesi ve tüm yaş guruplarında su içiminin öneminin vurgulanmasının dispeptik yakınmaları azaltacağı kanaatindeyiz.

Köksal ve arkadaşları tarafından yapılan çalışmada, Türkiye'de dispepsi yakınması olan hastaların \%54.3'ünün PPI veya $\mathrm{H} 2$ reseptör blokeri tedavisi aldığı tespit edilmiştir. Bizim çalışmamızda da benzer oranlarda hastaların \%50.3'ünün PPI veya $\mathrm{H} 2$ reseptör blokeri kullanımı mevcuttu (6). Acil servislere her gün onlarca dispeptik yakınması olan hasta başvuruları olmaktadır. Bizim çalışmamızda acil servise başvuran dispepsi hastalarının \%34'ünün bir gastroenteroloji uzmanına müracaat ederek endoskopik bir tanı aldığı tespit edilmiştir. Dolayısıyla, endoskopik tanı alan vaka sayısının neredeyse üç katı hasta tedavi almak için acil servislere başvurmaktadırlar.

Çalışmamızın en önemli kısıtlılığı tek merkezde yapılmış olmasıdır. İkinci olarak da acil serviste hastalara uygulanacak olan anketin süre açısından çok fazla zaman almaması gerektiği düşünülerek sadece gastrik intoleransa en fazla neden olan soruları içeriyor olması ve daha sonrasında da bahse konu hastaların mevcut yakınmaları ile hangi tanıları aldığı bilgisine ulaşılamamasıdır.

Çalışmamızda stres faktörü, gastrik intoleransa neden olan gıdaların fazla tüketimi, tütün ve antiinflamatuvar ilaç kullanımının dispeptik yakınmaları arttırdığı tespit edilmiştir. Bu çalışmanın ışığında acil servislere dispeptik yakınmalar ile başvuran hastalara hasta eğitimi amacı ile dispeptik yakınmaları tetikleyen durumları ve davranış haline dönüşmüş yaşam tarzı değişikliği gerektiren beslenme alışkanlıkları hakkında bilgilendirme broşürü verilmesinin acil müdahale gerektirmeyen başvuruları azaltacağı değerlendirilmektedir.

\section{"Tüm yazarlar herhangi bir çıkar çatışması olmadığı- nı beyan ederler."}

\section{KAYNAKLAR}

1. Özden A. Dispepsi (Dyspepsia). Güncel Gastroenteroloji 2012;16:272-82.

2. Özer B. Functional dyspepsia. İç Hastalıkları Dergisi 2011;18:153-7.

3. Nihat $O$, Ömer $Y$, Hakan D, Gülçin $P$, et al. Dispeptik semptomlarla beslenme alışkanlıkları, endoskopik ve histolojik bulgular arasındaki ilişki. Akademik Gastroenteroloji Dergisi 2006;5:110-5.

4. Türk ÖP, Demirel ZB. The role of nutrition in the management of dyspepsia symptoms. Bes Diy Derg 2017;45:258-63.

5. Özden A. Fonksiyonel dispepsi. Güncel Gastroenteroloji 2012;16:283-90.

6. Köksal AŞ, Oğuz D, Özden A. Türkiye'de birinci basamak sağlık kurumlarına başvuranhastalarda dispepsi görülme sıklığı. Akademik Gastroenteroloji Dergisi 2008;7:11-7.

7. Moayyedi P, Lacy BE, Andrews CN, Enns RA, Howden CW, Vakil N. ACG and CAG Clinical Guideline: Management of Dyspepsia. Am J Gastroenterol 2017;112:988-1013.

8. Pittayanon R, Leelakusolvong S, Vilaichone RK, et al. Thailand Dyspepsia Guidelines: 2018. J Neurogastroenterol Motil 2019;25:1526.

9. Zagari RM, Law GR, Fuccio L, et al. Dyspeptic symptoms and endoscopic findings in the community: the Loiano-Monghidoro study. Am J Gastroenterol 2010;105:565-71.

10. Kim SE, Kim N, Lee JY, et al. Prevalence and risk factors of functional dyspepsia in health check-up population: A nationwide multicenter prospective study. J Neurogastroenterol Motil 2018;24:60313.
11. Masoumi SJ, Mehrabani D, Moradi F, et al. The prevalence of dyspepsia symptoms and its correlation with the quality of life among Qashqai Turkish migrating nomads in Fars Province, Southern Iran. Pak J Med Sci 2015;31:325-30.

12. Karıncaoğlu $M$, Aladağ $M$, Sertkaya $A$, et al. Duodenal ülser ve ülser benzeri dispepsinin ayırıcı tanısında semptomlar. Akademik Gastroenteroloji Dergisi 2002;1:77-81.

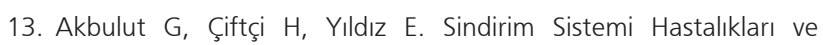
Beslenme Tedavisi. Sağlık Bakanlığı Yayını Şubat 2008; No:728.

14. Khademolhosseini F, Mehrabani D, Zare N, et al. Prevalence of Dyspepsia and its Correlation with Demographic Factors and Lifestyle in Shiraz, Southern Iran. Middle East J Dig Dis 2010;2:24-30

15. Borekci E. Prescribing trends of non-steroidal anti-inflammatory drugs in a tertiary care hospital in the middle Anatolia. J Contemp Med 2017;7:203-7.

16. Eminler AT, Uslan MI, Köksal AŞ, Parlak E. Non-steroid anti-inflamatuvar ilaçların üst gastrointestinal sistem yan etkileri ve önlenmesi. Güncel Gastroenteroloji 2014;18:333-8.

17. Saka M, Köseler E, Metin S. Gastrointestinal Sistem Hastalıkları ve Beslenme Tedavisi. Hatiboğlu Basım ve Yayım San Tic Ltd Şti. 2013:541-638.

18. Lee SY, Masaoka T, Han HS, et al. A prospective study on symptom generation according to spicy food intake and TRPV1 genotypes in functional dyspepsia patients. Neurogastroenterol Motil 2016;28:1401-8. 
19. Bektaş M, Çetinkaya H, Çalışkan D, et al. Park Sağlık ocağı bölgesinde 15 yaş üstü nüfusta dispepsi prevelansı. Akademik Gastroenteroloji Dergisi 2007;6:120-6.

20. Sinem D, Kaan S, Sibel K, Belgin Ü. Türkiye'de toplumda sigara içme sıklığı nasıl değiş̧iyor? Türkiye Halk Sağlığı Dergisi 2012;10:93115.
21. Çöloğlu B, Saka M. Dispepside beslenme. Güncel Gastroenteroloji 2016;20:214-7

22. Baltacı D, Sönmez C.I, Kara İ.H. Birinci basamakta dispepsiye yaklaşım. Turkiye Klinikleri J Fam Med-Special Topics 2015;6:20-7. 